Vol. 3, nº 1 | 1999

Varia

\title{
The creation and evolution of criminal law in colonial and post-colonial societies
}

Leslie Sebba

\section{(2) OpenEdition \\ Journals}

Electronic version

URL: https://journals.openedition.org/chs/936

DOI: $10.4000 /$ chs. 936

ISSN: 1663-4837

Publisher

Librairie Droz

Printed version

Date of publication: 1 January 1999

Number of pages: $71-91$

ISBN: 2-600-00356-8

ISSN: 1422-0857

\section{Electronic reference}

Leslie Sebba, "The creation and evolution of criminal law in colonial and post-colonial societies", Crime, Histoire \& Sociétés / Crime, History \& Societies [Online], Vol. 3, n | 1999, Online since 03 April 2009, connection on 22 March 2022. URL: http://journals.openedition.org/chs/936 ; DOI: https://doi.org/ $10.4000 /$ chs. 936 


\title{
The creation \\ and evolution of criminal law in colonial and post-colonial societies
}

\author{
Leslie Sebba'
}

Theoretical models of the legislative process are explored in order to seek an explanation of the phenomenon whereby post-colonial democracies frequently retain the legislation adopted by the imperial predecessor. This even applies to criminal codes, in spite of their presumed role in the controlling of colonial populations. A possible explanation is proffered in terms of a bureaucratic model of legislation, which seems to fit both colonial powers and some democracies. Under this model, the character and content of the legislation may depend as much upon the personalities involved in its drafting and promotion, as upon political or structural factors.

Cet article examine différents modèles théoriques relatifs au processus législatif afin de rechercher l'explication du fait que les démocraties postcoloniales conservent fréquemment la législation édictée par le pouvoir colonial antérieur. Ce constat vaut même pour les codes pénaux en dépit de leur supposée vocation à contrôler les populations colonisées. L'une des explications possibles repose sur un modèle législatif "bureaucratique" qui parâ̂t s'appliquer aussi bien au pouvoir colonial qu'à certaines démocraties. Dans ce modèle, le type et le contenu du droit peut dépendre tout autant des personnalités chargées de l'élaborer et de la promouvoir que de facteurs politiques ou structurels.

$\mathrm{T}$ The original focus of this research was the creation and evolution of criminal law in post-colonial societies - with special emphasis on Israel. However, one of the most striking (and seemingly surprising) features of the development of law in these societies is the fact that in many cases they have substantially retained the criminal codes enacted by the colonial power. Thus, rather than limiting the focus to the non-creation (or retention) of criminal law in these societies, it seemed appropriate to broaden the topic so as to include the creation of the laws generally prevailing today - by extending the analysis to the colonial phase of development. In the result, this historical phase became the focus of the study.

The topic under discussion here does not fit easily into a developed academic tradition. For while "it has long been recognized that the systematic study of the

1 Leslie Sebba is Associate Professor in the Institute of Criminology at the Law Faculty of the Hebrew University of Jerusalem. His recent publications include Third Parties: The Victim and the Criminal Justice System (Ohio State University Press, 1996) and two edited books: Social Control and Justice: Inside or Outside the Law (Magnes Press, 1996) and (with Gillian Douglas) Children's Rights and Traditional Values (Dartmouth - Ashgate, 1998). His main interests are penal policy, victimology (he serves as co-editor of the International Review of Victimology) and the sociology of law. 
social and legal context of legislation is an important means of understanding law and the legal process"2, relatively little has been achieved to implement this goa $1^{3}$. The growing literature on the sociology of law (or "law and society") lays relatively little emphasis on legislation, and much of the literature on legislation is concerned with its effects or its implementation rather than the process of its creation (ibid., p. 33). Studies of the creative processes are generally case-studies ${ }^{4}$ and give rise to methodological problems regarding their purpose: "These studies frequently vacillate between an effort to provide a comprehensive description of the passage of a law and an attempt to explain in causal terms why it was passed"s.

Moreover, in the context of the criminal law, the topics selected for study are generally those forms of deviance, such as juvenile delinquency, drug abuse and sexual deviance, which attract the energies of moral entrepreneurs seeking the imposition of a medicalised form of criminal law ${ }^{6}-$ or, more recently, involved in victim advocacy ${ }^{7}$. These are fruitful areas for the analysis of issues related to social control, but they are located in the margins of the criminal law proper.

Another type of approach has been to focus on the socio-legal functions of certain legal (mainly statutory) reforms in England, as seen in their historical perspective. Notable examples are the analyses by Jerome Hall (1952) of the law of theft, William Chambliss (1964) of the Vagrancy Laws and E.P. Thompson (1975) of the Black Act. These analyses tend to show how laws are created or manipulated by the ruling classes for the protection of their economic and political interests. This approach, as indicated, lays emphasis on the socio-political function of the legal development concerned, rather than the processes of its adoption.

Most of the above-mentioned literature has been concerned with the analysis of legislation in Western democracies. There is some (largely anthropological) literature relating to the imposition of law on colonized peoples 8 , but here the emphasis is on the conflict between the imposed and the traditional norms, rather than on the legislative processes ${ }^{9}$.

The studies referred to above tend to focus on particular legislative enactments or reforms rather than comprehensive codifications of the law. Codification (including the processes involved in its adoption) has also been the subject of academic analysis ${ }^{10}$. This literature, however, tends to be inward-looking, in that it sees the legislative processes as autonomous, rather than as a testing-ground for broadly-based sociological theories.

2 Tomasic (1980, p. 19).

3 See, however, the useful integrative surveys conducted by Tomasic (1980) and Hagan (1980), as well as the more recent work by Chambliss (1993) and his colleagues in the framework of the Society for the Study of Social Problems.

4 A notable exception is the pioneering study by Berk, Brackman and Lesser (1977) of changes in the Californian Penal Code between 1955-1971.

5 Hagan (1980, p. 623).

6 Cf. Hagan (1980).

7 Rock (1986); McCoy (1993); Scheingold, et al. (1994).

8 Notably Burman and Harrell-Bond (1979).

9 There is, of course, an extensive political science literature relating to the political aspects of the legislative process (see, e.g., the Legislative Studies Quarterly), but this literature adopts a very different perspective, laying emphasis on the respective roles of various institutions pertaining to the constitutional scheme.

See, e.g. - in the context of criminal law codification - Kadish (1978) and Friedland (1984). 


\section{THEORIES OF LEGISLATION}

The traditional analysis distinguishing between two hypotheses applicable to the role of law in society - the functional and Marxist, or "consensus" and "conflict" hypotheses ${ }^{11}$ has been applied specifically to the legislative process. Thus Hagan in his analysis of sociological studies of legislation differentiated between the "moral functionalists", who regard the law as an expression of "values and customs that are widely shared in society", and the "moral Marxists", for whom "the legal system is an apparatus that is created to serve the interests of the dominant class"'12. Tomasic, however, added a further dimension to this analysis ${ }^{13}$. He differentiated between those analyses in which the dichotomy was based upon values (consensus versus conflict) and those in which the criterion was interests - contrasting interest group theories which are elitist in orientation with those adopting a pluralistic approach. This analysis gave rise to a whole matrix of possible theoretical orientations based upon the above classifications ${ }^{14}$. Ultimately, however, it seems that the consensusversus-conflict dichotomy is implicit in both the "value" and the "interest group" approaches.

The above approaches seem all to be deterministic, legislation being perceived as the outcome of vested interests, and reflecting either a synthesis of such interests under the consensus-functionalist approach, or those of the dominant forces under the Marxist-conflict approach. Chambliss $(1993$, p. 9), too, sees law creation as the "resolution of contradictions, conflicts and dilemmas...inherent in the structure of a particular political, economic and social structure"; but his reference to "dilemmas" and his emphasis on the processual aspect of law-making suggest a "softer" model, and this is confirmed by the incorporation of "human agency" into this model ${ }^{15}$. Indeed, Chambliss adopts a "dialectical methodology" which "grants a role to choice, intentions, and the like (even envisioning a freely chosen future)"16 - albeit limited by the structural constraints referred to. In the case-studies referred to, however, the "human agency" element tends to remain abstract, and seems to be relating to interest-groups and other sub-sections of the population, rather than personalities.

"Personalities" are, however, one of the key elements in the analytical studies of law reform conducted by Martin Friedland (1984). Friedland, rather than invoking sweeping sociological theories, sees law reform as the result of "politics, personalities and pressure groups" (p. 44). In the context of contemporary lawmaking, he refers to the "constant interplay between public opinion, pressure groups and influential individuals" (p. 74). This analysis implies an open and nondeterministic legislative system - although passing reference is made to "the possibility of inordinate influence by powerful pressure groups..." (p. 112). It may thus be appropriate to name this construct a democratic model, which may in substance be regarded as a variant on the functionalist theme.

11 See, e.g., McDonald (1976).

12 Hagan (1980, p. 604-605), citing Richard Quinney.

13 See also Chambliss (1993) who identifies two derivatives of the functionalist and Marxist approaches, which he refers to as "pluralist" and "ruling class" theories.

14 Tomasic (1980, p. 27).

is Zatz, (1993, p. X).

16 J. Kenneth Benson, cited in Chambliss (1993, p. 9). 
The above-mentioned approaches all seem to assume that the legislative process is characterized by a high degree of purposefulness ${ }^{17}$ and rationality, deriving either from fundamental features of the socio-economic structure, or at least from the explicit views of articulate sections of the population. This is true both of the radical/Marxist/conflict analyses, which perceive this process as a conspiracy on the part of certain powerful elements in the social structure to further their self-seeking goals and interests, and of the consensus/functionalist/democratic analyses, which see the process as a framework designed to ensure that the final legislative product will reflect a fine balance between competing interest groups, thereby achieving if not consensus in the literal sense, at least a sort of lowest common denominator.

Consideration should also be given, however, to the possibility that legislative processes do not possess such rational and purposeful characteristics. Two such models may be envisaged. These models derive essentially from anecdotal evidence and are proposed somewhat tentatively; but at least one of the models will he highly pertinent to the subsequent discussion of colonial legislation.

The first of these models may he termed the bureaucratic model ${ }^{18}$. Under some parliamentary systems, including those following the Westminster model, parliamentary business, and in particular the bills which are ultimately adopted, are generated primarily by the government of the day ${ }^{19}$. The ministers of which these governments are composed rely, in turn, upon their senior advisers for this purpose. Thus, while a British minister might he largely motivated to introduce new legislation ${ }^{20}$, the content of this legislation will generally be determined largely by public servants; "...most legislation is conceived, drafted and all but enacted in Whitehall"21. Even where the legislation adopted follows from the recommendations of various public bodies (such as law reform committees), these bodies may also have included or have been influenced by officials. The procedure described here is a far cry from Dicey's image of a constitutional and substantially consensual process in which the dominating force is public opinion ${ }^{22}$. This phenomenon, i.e., the focal role of the civil servant in the governmental process (in substance the theme of the popular TV series "Yes, Minister"), has been the subject of academic analysis in recent times ${ }^{23}$; but relatively little emphasis has been placed in this context on the legislative process.

Specific evidence of this phenomenon is found in an account of the adoption of criminal justice legislation in England, where "It's not generally realized that civil servants brief their ministers not just behind the scenes but while actual debates are going on on the floor or in committee"24. It seems clear from the illustrations (in the context of criminal justice) provided by this source that the civil servant rather than the Minister is the guiding force behind legislative reform. In Israel, too, a

\footnotetext{
17 Cf. the discussion by Kidder (1979) of the relevance of intent in the imposition of law.

18 Cf. Chambliss (1976, p. 87).

19. Mezey (1979), in his comparative analysis of political systems, characterizes the legislatures of the type referred to here as "reactive".

20 Zander (1994, p. 5).

21 Miers and Page (1990, p. 39).

22 Cf. Tomasic (1980).

23 See Potter (1986), and the references therein on p. 11, fn.22.

24 Professor Anthony King, cited in Zander (1994, p. 59).
} 
perceptive jurist drew attention, in a short monograph devoted to this topic, to the critical role of the ministerial legal adviser in the creation of legislation ${ }^{25}$.

This model of the legislative process may be less appropriate in the context of political systems in which the legislature has a greater degree of independence from the executive arm, such as the United States ${ }^{26}$. Moreover, the emphasis under the bureaucratic model is very different from Friedland's attribution of law reform to "politics, personalities and pressure groups" (see above) - more particularly in that he adds "public opinion" to his list of main ingredients ${ }^{27}$. This may be partly explained by the emphasis in his analysis on Canada (although his model purports to be applicable to the U.K. too). It may also be true that the bureaucratic model is presently losing ground in an era of more participatory politics.

It may also be argued that the dynamics of the legislative process described here are relevant mainly to what is sometimes known as "lawyers' law", rather than to areas of the law more closely related to controversial political issues, where the input will be wider. However, even if both this differentiation is valid and the conclusion correct, the model remains at least partially valid - and may apply in particular to criminal law (see below). If this is indeed the case, it raises questions about the validity - or at least the universality - of both the consensus and the conflict views of legislation; for legislation would reflect the view neither of the general public, nor of powerful interests groups in society, but of a handful of (or sometimes even individual) public servants. The actions of such individuals will, of course, reflect certain social, economic and political values (whether sectarian or consensual); but these will be applied in isolation from the broader political processes.

What, indeed, would be the character of legislation emanating primarily from a bureaucrat? His (or her) natural inclination would be to antagonize as few persons as possible, and this might be expected to be reflected in the legislation. In rare cases, a secure official, taking pride in his or her professional background and/or competence, might attempt more ambitious reforms; and this might be true also of an outsider, called in from academic or private practice. These alternative roles which may he labelled the "obfuscated" and the "enlightened" bureaucrat - will be considered further in the course of the subsequent discussion of colonial legislation.

The second - and more tentatively suggested - model is the fortuitousness model. Anecdotal evidence describes many haphazard (or even negligent) occurrences in the course of the legislative process, such as chance absences from votes (including votes in committee rooms - or even at plenary sessions, with only a handful of legislators participating), inattention to drafting, and errors in voting resulting from misunderstandings. Clearly such disarray may play a part in the nature or content of the legislation adopted. However, it seems unlikely that such forces actually dominate the legislative process. Thus, this model should perhaps be regarded as a force modifying the three previous models rather than as an independent model.

25 Bar-Niv (1971). See, generally, Sebba (1995), alluding also to the dominant role (particularly in the area of civil law) of the head of the legislation department in the Ministry of Justice. In recent years, however, greater initiative has passed to "private members" of the Knesset in the instigation of legislation, including criminal legislation (see ibid.).

26 Cf. Mezey (1979).

27 Friedland (1984, p. 74). 
Four tentative models of the legislative process emerge from the foregoing discussion: (1) a (democratic) consensual model; (2) a (Marxist) conflict model; (3) a bureaucratic model; and (4) a "fortuitousness" model. The next question to consider is which of these models are relevant to the colonial situation.

\section{COLONIAL LEGISLATION}

Under a colonial regime the applicability of the democratic or consensual model is by definition precluded; laws are imposed by the mother country on a subject people. It is true that an enlightened colonial regime may endeavour to take account of the wishes of the local population (or at least of certain sectors of that population) when enacting new legislation. But whereas for Dicey taking account of public opinion was an essential feature of a democratic legal system, in the context of a colonial regime such considerations are at the rulers' discretion. Interest in ascertaining the views of the local population, if any, may derive not primarily from democratic ideology, but rather from pragmatic considerations, namely the desire that the law will be accepted and implemented with a minimum of friction and controversy ${ }^{28}$.

On the other hand, the (Marxist) conflict model presents a more plausible model for the dynamics of colonial legislation. To colonial governments are attributed the desire to exploit the native population, to "divide and rule", and to maintain hegemony for its own sake (cf. Tomasic's "elite interest group" referred to above). The use of the instrument of law for this purpose clearly suggests itself, especially as wide powers of law-making rest with the colonial administration, with some control exercised by the home administration - but little intervention on the part of more democratic forces. In her conclusions to a survey of the literature on law and colonialism Merry (1991, p. 917) concludes that "Law often serves as the handmaiden for processes of domination, helping to create new systems of control and regulation". However, the more blatant expressions of repressive, and in particular exploitative, domination are found in land and labour law, rather than the criminal law. Such illustrations of the use of law to secure capitalist transformations in Rhodesia and Tanganyika may be found in Sumner's Crime, Justice and Underdevelopment $(1982)^{29}$; but Sumner also notes the use of penal provisions (albeit not usually in the penal codes) for the purposes of the maximization of production and minimizing of costs, by creating forms of pseudo-slavery.

Economic patterns and "strategies of rule" varied widely from colony to colony (Merry, 1991, p. 891), and the above illustrations may not be typical. It was nevertheless probably common for standard penal provisions to be widely drawn, to facilitate control of the local populations. Some illustrations from the legislative history of the Palestinian mandate appear to illustrate this phenomenon. The Criminal Procedure Ordinance (Arrest and Searches) of 1924 vested very wide powers of arrest in the Palestine police, while bestowing minimal rights and powers

28 Even for Lord Macaulay, whose enlightened views will be described below, the importance of taking account of local opinion derived primarily from the need to forestall criticisms which might otherwise emerge in the local press. On the other hand, the principle that the local press should be free was for Macaulay a matter of ideology.

29

See also Merry (1991, p. 909), reviewing The Political Economy of Law, by Ghai et al. (1987). 
on the local population. A second example is the provision added to the Criminal Code Ordinance of 1936, in the later drafting stages, to provide the government with a somewhat vague and embracing power to punish an act "which may cause or tend to a public mischief" on the grounds that "it might be useful here, particularly in time of disturbances $!^{30}$ ". This provision is somewhat reminiscent of the vagrancy laws in early English history; the vagueness of which has been seen as providing a legal basis for the control of populations perceived as dangerous to the establishment ${ }^{31}$. Thus colonial legal history is replete with evidence in support of the conflict model ${ }^{32}$.

"Fortuitousness" is also on occasion a feature of colonial legislation. Certain developments appear to have been attributable to poor communication systems, while errors (due partly to ignorance of the law in the mother country) have sometimes exercised a lasting influence ${ }^{33}$. Such features, however, appear to play only a secondary role in colonial legislation too.

The overriding character of much colonial legislation, on the other hand, seems rather to accord with the bureaucratic model. The two possible forms which this model may assume - the "enlightened" as compared with the "obfuscated" bureaucracy - may apply with greater force to colonial rather than to non-colonial administrations, for the personnel concerned operated in a greater degree of isolation and with greater freedom from the pressures of "checks and balances" prevailing in the mother country ${ }^{34}$. The following section will develop these variants of administrative/ legislative styles as applied to various colonial regimes in the British Empire - notably India and Palestine ${ }^{35}$.

\section{AN ENLIGHTENED BUREAUCRAT - MACAULAY'S INDIAN CODE}

Thomas Macaulay (1800-1859) is a figure well-known to historians but seemingly neglected by sociologists of law. His unusual characteristics render the legal history of India a unique phenomenon. He was described by the late Professor Cross as "a distinguished politician and a great man of letters [ Macaulay was offered a Chair in history at Cambridge] but hardly a jurist" ${ }^{\prime 36}$. Nevertheless, he was called to the bar before entering politics and, after holding office as Secretary of the Board of Control of India, accepted the appointment as "Law Member" of the

30 "The language is that of the Attorney General, who in fact attributes the suggestion that such a provision be added to "one of the leading advocates"' (Abrams, 1972, p. 45).

31 Chambliss (1964).

32 However Merry also sees the legal norms as providing constraints for the repressive systems that were prevalent, and as providing "arenas for resistance" (Merry, 1981, p. 917).

33 An illustration of this, albeit on the judicial rather than the legislative level, was the misinterpretation by Palestinian judges of the English corroboration rule in sexual assault cases; see Sebba (1968); cf. also Likhovski (1995, p. 341-342).

34 The British Empire was administered by the Colonial Secretaries exercising royal prerogative powers. Parliamentary control was thus more limited here than in respect of other areas of government.

35 In formal terms, Palestine was not a colony but a Mandated territory administered by Britain on behalf of the League of Nations.

36 Cross (1978, p. 519). However the analysis by Cross of some of the provisions of Macaulay's code suggests a more positive view of the latter's legal talents ! 
Governor-General's Legislative Council. The Law Member was to be, in the words of James Mill (the father of John Stuart Mill) "versed in the philosophy of men and government" ${ }^{37}$ - a role somewhat reminiscent of Plato's philosopher-king ${ }^{38}$; this was a position that Macaulay himself (when a Member of Parliament) had helped to create under the Charter Act of 1833 - in effect India's constitution ${ }^{39}$. Macaulay arrived in India in 1834, and one year later it was decided that India needed a penal code. Although formally he was merely one of the four members of the Law Commission entrusted with this task, in practice "Macaulay was virtually the sole author" of the draft code submitted to the Governor-General some two years later ${ }^{40}$.

Although Macaulay was on record as a critic of the utilitarians, the style of the penal code he drafted strongly suggests the influence of Jeremy Bentham, who had indeed advocated the codification of the Indian Penal Law ${ }^{41}$. According to Stokes ${ }^{42}$, Macaulay did not fully adhere to Bentham's political philosophy, and he "had no sympathy for the planned, centralized, bureaucratic state which Bentham had envisaged in all its minutiae" (in his Constitutional Code) ${ }^{43}$, but he internalized Bentham's jurisprudential concepts ${ }^{44}$. Thus Macaulay's Penal Code sought to maximize clarity of language and to minimize technicality. Following Bentham, he rejected the verbiage of the "preamble" (partly on the ground that there might be disagreements as to the purpose of a particular law), but instead suggested that consideration be given to the possibility of publishing the minutes of the Legislative Council so that the reasoning of the legislation could be generally known ${ }^{45}$. He himself published his own legislative minutes ${ }^{46}$, which have themselves become a minor classic. Clarity and comprehensibility - the two underlying principles of the code $^{47}$ - were also to be achieved by providing, as an integral part of the code, illustrations of the principles stated therein, described by the famous jurist James FitzJames Stephen as "an entirely new and original method of legislative expression"48. This approach seems to have been aimed at reducing judicial discretion - in accordance with classical penal law doctrine: precedents were effectively being set in advance. In particular, there was perceived to be a need to remove the confusion

37 Stokes (1959, p. 178).

38 Stokes (1959, p. 176-177) describes Mill's Benthamite concept of the legislator: "His pedigree is that of the eighteenth-century philosophe, and it reaches back to Solon. Legislation is a science, a task for the ablest philosophic mind, a subject for dispassionate study and expert knowledge...".

39 On the dual control of India by the East India Company and the British Parliament, see Cross (1978:520, fn.3).

40 Cross (1978, p. 522); Dhagamwar (1992, p. 7).

41 Jain (1977). James and John Stuart Mill were also highly involved in Indian afffairs: see Stokes (1959).

42 Stokes (1959, p. 192).

43 Cf. also Edward Livingston, author of the Louisiana Code, who believed in extensive state intervention to prevent crime (Kadish, 1978).

44 The differentiation between political and jurisprudential philosophy may not always be clear. Thus Stokes (1959, p. 213) attributes to Macaulay a "grandiose conception of a pyramid of codes". Here the jurisprudential thinking seems to merge with the political philosophy.

45 Dharker (1946).

46 See Dharker (1946).

47 See the Law Commissioners' letter which accompanied their submission of the code (Dharker, 1946, p. 264).

48 Cross $(1978$, p. 524). 
caused by the application of religious criminal law (Muslím in some areas, Hindu in others) upon which colonial Regulations had been superimposed ${ }^{49}$. In his parliamentary speech on the Charter Bill, Macaulay had advocated "uniformity where you can have it, diversity where you must have it - but at all costs certainty" 50 .

Further, while a patriot, Macaulay did not believe that existing English law was perfect. Macaulay's code was influenced primarily by English law - it was subsequently described by Sir James FitzJames Stephen as "the criminal law of England freed from all technicalities and superfluities..." - but the departures were so extensive that it might be better regarded as "an entirely new thing"51. For, following the ethos of the utilitarians, the code was intended to meet universal criteria. In the spirit of Bentham's Codification Proposal, "the law-giver like Solon was to be a foreigner, versed in the universal principles of legislation, and free from local prejudice and interest"52. It thus also incorporated a number of provisions of the recently drafted Louisiana Code, as well as the French Penal Code - both, in turn, influenced by Bentham ${ }^{53}$.

Moreover, although under Benthamite principles "local knowledge was of minor importance" 54 , and Macaulay believed in the superiority of European values over Indian, Macaulay did take account of the fact that he was legislating not only for the European settlers, but also for the native Indians. It was therefore his policy to ensure that opportunity be provided for the expression of comments on any proposed legislation. While the time taken to draft the penal code - as well as the additional twenty-three years which elapsed until it was finally enacted - allowed plenty of time for reactions in the instant case, Macaulay's standing orders for the proceedings of the Legislative Council established a general principle to the effect that a period of six weeks was to elapse between the promulgation of draft laws and their enactment, so that local public opinion could he taken into account ${ }^{55}$ (This concept had in principle been laid down by the "Court of Directors"). However, this six week delay may generally have been of little assistance to most of the natives since pending bills, unlike the legislation finally adopted, were not translated into local languages ${ }^{56}$. On the other hand, Macaulay had no great sympathy for a "public opinion" which meant "the opinion of five hundred persons [i.e., the European settlers] who have no interest, feeling or taste in common with the fifty millions among whom they live" 57 .

49 Stokes $(1959$, p. 225$)$. "The criminality of a person's actions often depended on who he was - his caste, his religion, whether English or native - and on which of the presidencies he happened to be tried in" (Kadish, 1978, p. 1109) (Cf. Maine's description of India as "empty of law" (Jain, 1977)!). Jain (1977, p. 505).

Kadish (1978, p. 1109-1110).

Stokes (1959, p. 178).

Ibid., p. 226.

Ibid., p. 178.

Dharker (1946, p. 22-23).

Dharker (1946, p. 35). As to the laws themselves, cheap vernacular copies were to be made widely available (Stokes, 1959, p. 194).

Cited in Dharker (1946, p. 37). 
The need for codification derived in Macaulay's view less from the superiority of western norms but rather from the chaotic nature of the existing system ${ }^{\text {s8 }}$. Moreover, Macaulay argued in favour of having a number of Law Commissioners who in combination would have a greater understanding of the native population ${ }^{59}$. Further, while Macaulay's code seems to have incorporated little native customary law" it "takes notice of, and tries to deal with, some of the special problems of India"61.

Macaulay's objective of the introduction of a new body of law met with "a storm of criticism" on the part of the judicial establishment. In the words of a contemporary Anglo-Indian judge, the code was seen as "calculated to produce a degree of confusion and difficulty which has never yet been found in administering the criminal justice of any civilised country"62. Civil servants questioned "the wisdom of enacting a law which declined to draw exclusively upon any one system of law, choosing instead either to borrow from several, or to rely on abstract theories of jurisprudence" 63 . Such objections, coupled with the resignation of Macaulay in 1838 and other new appointments in the Indian administration ${ }^{64}$, account for the delay in the code's adoption. Moreover, subsequent administrations sought - and sometimes effected - their own modifications to the Code. In the circumstances it is perhaps surprising that, more than two decades after Macaulay's draft was completed (and one year after his death), the Code was actually adopted - thanks in part to the professional editing by Sir Barnes Peacock, a subsequent "Law Member"65.

Macaulay's enlightened rationality was reflected in many of his views. He was against capital and corporal punishment, and the use of the criminal code to restrict civil liberties ${ }^{66}$. He looked favourably on the possibility of eventual selfdetermination on the part of the Indian people. While emphasising the importance of exporting British products and "the diffusion of European civilisation", he took the view that it would be "far better for us that the people of India were well-governed

58 See above; and see Macaulay's speech to Parliament on the enactment of the Charter Act (Jain, 1977, p. 504).

s9 See Dharker (1946, p. 256-257). The Commission would therefore comprise "partly persons sent down from England and partly members of the Civil Service" (Macaulay, ibid.). However, although Macaulay held the view that native Indians would eventually hold public office, he did not specify that these were the "members of the civil service" he had in mind here.

60 A claim has been made for the continued influence of Moslem Law, at least in the determination of penalties; see Bannerjee (1963, p. 123).

61 Jain (1977, p. 555). "The Commission was careful to consider the special Indian conditions so as to avoid making conduct punishable when no sufficient advantage was likely to accrue from applying the criminal law; as also from the standpoint of making special provisions against crimes peculiar to India" (Jain, 1977, p. 555).

62 Cited in Cross (1978, p. 523).

63 Dhagamwar (1992, p. 88).

64 In particular, some of the subsequent Law Members were against introduction of the Code: see Stokes (1959, p. 261); Char (1963, p. 182), and Cross (1978, p. 524).

65 Char (1963, p. 186-187). In praising this combination of talents, Sir James Stephen commented that "an ideal code ought to be drawn by a Bacon and a Coke" (Char, 1963, p. 187, n. 77).

66 See Kadish (1978, p. 1114). However, Kadish attributes these opinions to practical considerations on Macaulay's part, rather than to ideology. (In this he differed from Livingston, who sought to use the criminal code he drafted for the state of Louisiana as a weapon against the abuse of civil liberties (lbid.)). 
and independent of us, than ill-governed and subject to us"67. He also insisted on the principle of a free press, and the denial of legal privileges to Europeans - principles which rendered him highly unpopular in certain quarters. Finally, in the matter of local taxation for local purposes, Macaulay was insistent that the local population should decide ${ }^{68}$.

In contrasting Macaulay's enlightened views with the conservativism of many of his critics it should not be forgotten that in the last analysis the model described was nevertheless a bureaucratic one. In spite of the concession to "public opinion" and the incorporation of various extraneous legal concepts, Macaulay was ultimately imposing a foreign (in this case English-based) legal system on an indigenous population ${ }^{69}$. He was, of course, unaware of the approach of the later anthropological school, or of contemporary sociological approaches which question both the practicality and the ethics of the imposition of so-called "advanced" legal systems on so-called "backward" peoples ${ }^{70}$. However, while he did indeed believe in the superiority of western values and education ${ }^{71}$, the legal codes he wished to impose were, as noted above, perceived by him (following the utilitarian philosophy) to be universal rather than culture-specific.

\section{OBFUSCATED BUREAUCRATS - THE PALESTINE MODEL}

The pioneering achievements of Thomas Macaulay - in terms both of his concept of legislation and the content of his code - did not provide the model for future colonial developments. "Whereas the Indian Penal Code was the work of a commission of some of the most distinguished lawyers of the early years of Victorian England who were deeply imbued with Benthamite inspiration and reforming zeal...the average colonial Criminal Code has come out of the AttorneyGeneral's chamber probably as the work of a legal draftsman"72. The expansion of the British Empire and the consequent proliferation of colonial legislation was doubtless a crucial factor in the process of bureaucratization; perhaps also the intellectual climate of the late Victorian and subsequent period could not rival that of the early nineteenth century. Whatever the explanation, the colonial code model most widely adopted during the nineteenth century was not the Indian Penal Code

67 From Macaulay's speech in the Charter debate, cited in Stokes (1959, p. 43).

68 Dharker (1946, p. 163).

69 It is to the credit of the judicial critic cited above that he purported to object to the novel code as being "new to those who are to dispense the law as to those who have to live under it" (See Cross, 1978, p. 523 - emphasis added). On the Indian objections to this aspect of the criminal codification project, see Brown $(1989$, p. 23). In other areas, Macaulay appeared to have demonstrated even less sympathy for indigenous cultures, being totally scornful of native Indian education and literature in his insistence on the need for its anglicization (lbid., p. 521).

70 See, e.g., the discussion in Lloyd (1979, p. 648). In conjunction with the utilitarians, Macaulay also had a somewhat ambivalent attitude to the democratic component of the legislative process. Laws were best adopted by a small body of experts - albeit incorporating some representative elements (Stokes, 1959, p. 177-178). Cf. also Bentham, who "found himself more at home with the enlightened despots than turbulent political assemblies" (Stokes, 1959, p. 177).

71 Cf. Stokes (1959, p. 57), and above, fn. 33. On this characteristic of colonialism, and Edward Said's concept of "Orientalism", see Darian-Smith (1996).

Elias (1962, p. 148). 
but that of Queensland, which was based on the well-known Digest of the Criminal Law produced by the conservative judge and jurist James Fitzjames Stephen ${ }^{73}$ published in 1877, and intended as "a first step towards a Code"

The Queensland Criminal Code, adopted in 1899, was largely the work of Sir Samuel Griffith. Like Macaulay, Griffith, too, was a lawyer (when he drafted the code he was Chief Justice of Queensland), a politician and a man of letters (known for his translation of Dante's Divine Comedy). However, he lacked Macaulay's inspiration and innovative orientation. In Griffith's view, codification meant essentially "the reduction of the existing law to an orderly written system", for which purpose he relied heavily on Stephen's Digest and the subsequent Draft Code of the Royal Commission ${ }^{75}$, although a greater degree of creativity was evident in his drafting of the general principles of responsibility ${ }^{76}$.

Another codifier emerging in the late nineteenth century was R.S. Wright. He, too, had a background in the classics, and published books in this field ${ }^{77}$. While still a young man he was invited by the Colonial Office to draft a penal code for Jamaica, with the intention that it should be subsequently adapted to the needs of other colonies $^{78}$. In making a detailed comparison between the codes of Wright and Stephen "the two principal rivals in codifying the criminal law in the British Empire in the second half of the nineteenth century"79, Friedland found the former to be more progressive and "in many, if not most, respects... a much better Code"80. Perhaps because of its progressive elements, Wright's code was not adopted in Jamaica; and while widely praised was eventually adopted only in British Honduras, Tobago and the Gold Coast ${ }^{81}$, in sharp contrast to the widely adopted Queensland code.

It might be arguable that the adoption of Stephen's code, designed for the population of England (although never adopted in that country) was in principle not totally unsuitable for Queensland, an Australian state, composed mainly of migrants from the mother country or their descendants. What, however, could the cultural or normative standards of such a population have in common with those of the tribesmen of Nigeria, or the Turkish-Greek or Arab-Jewish melanges of Cyprus and Palestine respectively? For the same code (subject to relatively few modifications) was adopted in all these locations, as well as a dozen others" ${ }^{82}$. Thus, the "Palestine Model" of the present sub-heading is in fact the Queensland model; but it is its adoption in Palestine - the direct importation of an already existing code to a colony

73 Elias, too, cites Stephen's Digest as the main inspiration of the legal draftsmen responsible for many of the colonial codes (Elias, 1962, p. 148, fn. 13).

74 Kadish (1978, p. 1122). In the following year Stephen did indeed draw up a draft code for the British Parliament. This was revised one year later by a Royal Commission, comprising Stephen and three High Court judges (Kadish, 1978, p. 1122).

75 See preceding footnote.

76 Shachar (1979, p. 84-85).

77 Friedland (1984, p. 4).

78 Ibid., p. 5.

79 Friedland (1984, p. 44).

so Jbid., p. 1.

81 Friedland (1984, p. 35-36).

82 The interrelationship between the codes has been analysed by Abrams (1972), and Shachar (1979). 
(or in this case a mandated territory) with a heterogeneous population - that characterizes the phenomenon being described here.

The replication of this version of the English criminal law in numerous colonies had the overriding advantage of familiarity and therefore convenience for the majority of the administrators - whether they arrived from the mother country or from another colony which had already adopted this model, as well as being acceptable to the Colonial Office officials ${ }^{83}$. In the Palestine case, the decisionmaking process by which the code was adopted combined this bureaucratic approach with an autocratic one, as reflected in the Palestinian High Commissioner's declaration ${ }^{84}$ that "I have decided on the advice of the Chief Justice and the Attorney General to adopt the Cyprus Criminal Code as the model".

Various pressures were exercised in favour of a more flexible approach. In Palestine (unlike India) a unified system of penal law, namely the Ottoman Law itself strongly influenced by the French Law - had been in force for a long period of time and was familiar to much of the local population. However, it is clear that when Attorney-General Bentwich argued in favour of a more extensive retention of Ottoman Law provisions, in order to take such factors into account, he was regarded as a nuisance ${ }^{85}$. In the event, however, a few of the Ottoman provisions were retained, notably relating to homicide ${ }^{86}$.

In some colonies, moreover, support was expressed specifically for the Indian model. However, it seems that the very characteristics which made this code attractive to some - namely, its attempt to improve upon and simplify the existing common law, taking into account its prospective application to indigenous populations - rendered it unattractive to conservative bureaucratic minds. In this connection the detailed account of the adoption of the Queensland model in the African colonies in preference to the Indian $\operatorname{code}^{87}$ makes fascinating reading.

In 1904-1905, Sir Walter Egerton, the High commissioner of Southern Nigeria, strongly favoured the introduction of the Indian model into that colony. The legal advisers to the Secretary of State for the colonies (named Cox and Riley) favoured the Queensland model, which was the basis of the Northern Nigerian code (drafted during this period by Chief Justice Gollan). Egerton's reaction was strident:

"I cannot doubt that any unbiased person will consider the Indian Code far simpler and better suited to the needs of an uncivilized or semi-civilized population (sic!). The population of India has many things in common with the population of Lagos and Southern Nigeria. The latter has nothing in common with the population of Queensland"88.

The Secretary of State himself (Lord Elgin) supported this view:

"The Indian Penal Code has stood the test of fifty years with wonderfully few alterations. It was specifically designed for a semi-civilized population by one of

83 In civil law matters, however, the view was widely held among colonial officials that English law was too advanced to be appreciated by the native populations: see Likhovski (1995).

84 Cited in Abrams (1972, p. 27).

85 Shachar (1979, p. 105-106, fn. 154a).

36 Generally, however, Bentwich was in favour of the introduction of English law in Mandatory Palestine in the interests of progress: see Likhovski (Ibid).

87 Morris (1970 and 1974).

Morris (1970, p. 146). 
the greatest intellects of the nineteenth century... Surely it is a mistake to now adopt an untried Code designed for a white population in view of this Code which has proved so successful in India and has been extended to various Crown Colonies"89.

This last passage drew the comment "only Eastern colonies" from the legal advisers, who were able to ensure that no new code was adopted at that time, paving the way for the application of the Queensland model on the amalgamation of Northern and Southern Nigeria a few years later (in 1914).

The conservative bureaucratic view consistently prevailed in the course of the debate on the legislation of African penal codes. The most telling illustration is that of East Africa. These territories initially adopted Macaulay's Code ${ }^{90}$. This was clearly anathema to the bureaucrats, who objected to the placing of "white men under laws intended for a coloured population despotically governed", and in this instance they received some support from the European settlers ${ }^{91}$. A single notorious trial, in which a defendant perpetrating a fatal assault received a light sentence, provided the excuse for the repeal of the Macaulay codes and their substitution by the Nigerian (Queensland) model. Both the Governor and the Chief Justice of Kenya expressed reservations about this change, but Bushe, the legal adviser to the Secretary of State, "was adamant" - and the retrogressive measure was adopted.

As in the Southern Nigeria case referred to above, this episode illustrates the triumph of bureaucracy over rationality ${ }^{92}$. It also provides a link between the lawmaking process of the colonial and democratic regimes - the role of the legal adviser being predominant in both. The "Yes, Minister" phenomenon seems not to be peculiar to certain types of contemporary democratic regimes ${ }^{93}$, but seems also to have manifested itself in the colonial context.

\section{POST-COLONIAL LEGISLATION}

As noted in the opening section of this article, one of the interesting features of post-colonial regimes is that, having finally freed themselves of the shackles of colonial domination, with (under many analyses) its concomitant imposition of a presumptively oppressive normative system designed to serve the interests of the colonial power - relatively little is done on the part of these new regimes to replace this system. The post-colonial legislative system may thus differ little from the colonial system.

Thus, in the case of Palestine/Israel, although a large number of amendments have been made to the Criminal Code Ordinance of 1936, and a Hebrew formulation

s9 lbid., p. 147.

90 Morris (1974, p. 13). Zanzibar enacted such a code in 1867, Kenya in 1897, Uganda in 1902, and Tanganyika in 1920 (Morris, 1974, p. 13).

lbid.

92 It should be pointed out, however, that there were certain interests operating in favour of the Indian model. Both Sir Walter Egerton and Lord Elgin had personal experience of this model, so that the preference for the familiar over the unknown did not operate for them. Another factor was that the greater simplicity of this code rendered unnecessary the appointment of stipendiary magistrates with the additional costs involved (See Morris, 1974, p. 13).

Mainly those with "reactive" legislatures - see above, fn. 19. 
was finally enacted in 1977 , much of the substance of this Code remains in force today - half a century after independence, while the "General Part" was reformed only in 1994. Moreover other enactments, such as the Police Ordinance, the Prisons Ordinance and the Dangerous Drugs Ordinance, although translated into Hebrew and frequently amended, still bear the Mandatory nomenclature of "Ordinance". It seems that Israel is by no means unique in this experience, and that other ex-colonial nations retained their colonial criminal codes for several decades after independence ${ }^{44}$.

The question which is raised here is, therefore, as follows: How is it that the white settlers, the African tribesmen, the Jews and the Arabs, having thrown off the yoke of imperial domination, have been so slow to repeal the modified version of the English criminal law so arbitrarily imposed upon them? This question seems pertinent whichever theory of colonial legislation is the valid one - whether such legislation constituted an expression of a policy of domination and exploitation, whether it was the fruit of bureaucratic pressures, or whether it was the result of chance. Before considering some possible explanations for the above phenomenon, a few observations will be made on the development of criminal law reform in postindependence Israel.

By and large the substantive criminal law, at least in Israel, may be said to pertain to "1awyer's law". The general public generally shows little interest in the definition of larceny, arson, or even murder - although the question of homicide in selfdefence against a background of either political or domestic violence has given rise to public debate, and the definition of rape, too, has been of concern to the feminist lobby, resulting in reforms in these areas ${ }^{95}$. Even sentencing provisions are not widely debated by the public, except when they raise sensitivities in the area of domestic violence, or where there is a "moral panic", such as periodically occurs in the context of drug use - particularly where minors are concerned. Such occurrences give rise to calls for - and sometimes to the adoption of - minimum penalties, which are otherwise not an integral part of Israel's criminal justice system ${ }^{66}$.

Subject to the above reservations, criminal law legislation is seen to be a matter for the professional personnel at the Ministry of Justice (and, where appropriate, the legal adviser of the appropriate ministry ${ }^{97}$ ) and, to a lesser extent, the legal community in general. Pressure to change the law may arise from judicial exposure of gaps in the present law, from controversial judicial interpretations of that law or following the recommendations of a professional committee. Alternatively, an activist Minister of Justice may regard law reform as a worthy political or professional objective. Further, since the political parties have adopted the system of

94 Morris (1974).

95 See secs. 300A and 345 of the Penal Law, 1977 (as amended).

* The pressure for the adoption of mandatory minima for sex offences and domestic violence led in 1996 to the establishment of a public committee, headed by a Supreme Court Justice, to reconsider the sentencing system. Its recommendations are now being considered by the government.

97 See above, text by fn. 25. Reference was made there to the pivotal role of the head of the department of legislation in the Ministry of Justice. Shachar (1992) has described the activities of Prof. U. Yadin, who fulfilled this role during the early years of independence, and saw it as his mission to explain the evolving legislative system to the general public - including the use of radio for this purpose. In spite of the constitutional differences between colonial India and independent Israel, there seems to be a close parallel here between the roles of Macaulay and Yadin respectively! (Yadin, however, was a civil law specialist). 
selecting their candidates by means of "primaries", much legislation is now initiated personally by "private members" - in order to demonstrate legislative activity on their part ${ }^{98}$.

On the other hand, the forces operating against law reform seem to be strong. As noted above, criminal law reform is almost exclusively a matter of concern to lawyers, and lawyers, having been trained in the existing system, have a vested interest in the status quo. This interest may combine with interests of other kinds: an earlier draft for the general part of a new criminal code, incorporating a greater structurization of the sentencing provisions, was abandoned owing to the objections of the judiciary to the curtailment of their discretionary powers. On the other hand even during the post-colonial period reform is seen - or at least used to be seen - as more acceptable when it followed the lead of the English system, whether in the context of legislation ${ }^{99}$ or precedent. Moreover the provisions which specified that the Criminal Code should be interpreted in accordance with English law, and that gaps in the law should be filled by reference to English law, remained in effect for more than two decades after independence, and the Israeli legal system thus became weaned from this dependence relatively slowly ${ }^{100}$.

\section{CONCLUSIONS}

This article has considered various models of the legislative process, and particularly of codification processes' in colonial and post-colonial societies. The point of departure for this overview was the phenomenon whereby many postcolonial societies have been slow to abandon codes which were imposed upon them by the colonial power - in the case of Israel, the Queensland-Nigeria-CyprusColonial Office criminal code - generally with only minimal concern for the local culture and for the previously prevailing norms. A number of alternative explanations will now be considered by way of explanation of this phenomenon.

(1) One possible explanation is that legal norms are (or should be) in substance universal, so that the adoption of similar penal codes by different peoples is only natural. This seems in substance to have been the view of Macaulay and the Benthamites alluded to above. This view is inherent in the old concept of mala in se, accepted by Blackstone and others ${ }^{101}$. Some support for this view is found in the replications of Sellin and Wolfgang's measurement of delinquency, which elicited from various population samples assessments of the relative seriousness

98 See above, fn. 25.

99 Thus the repeal of the rule in Hollington $v$. Hewthorn, which had held evidence of criminal judgments to be inadmissible in civil cases, followed its repeal in England. The introduction of community sentences also followed the English example.

See the Law and Administration Ordinance (Amendment No. 14) Law, 1972, repealing sec. 4 of the Criminal Code Ordinance, which provided that the Code should in principle be interpreted according in accordance with the English law. A more general provision for filling gaps in the law by reference to "the principles of common law and equity current in England", enacted in the first years of the British Mandate, was repealed in 1980 by the Foundations of Law Act, to be replaced by more "indigenous" principles, viz., "the principles of freedom, justice, honesty and peace of the Israeli heritage" (Bein, 1995, p. 134-135). 
of different offences, and which claimed to have arrived at similar results in different cultures ${ }^{102}$. However, other comparative work ${ }^{103}$ as well as much anthropological literature would seem to question this hypothesis. Moreover the conflict hypothesis referred to earlier, if valid, posits a conflict of values and interests within societies, thereby leaving little room for consensus among societies.

(2) Another possible explanation is that whatever the legal, national and cultural origins of the imported code, its interpretation and application subsequently develop independently, so that in practice it becomes autonomous - and in effect indigenous. Thus, in the Palestine/Israel context, as in other colonies, the view was not unanimous, even during the Mandatory period, that enactments based upon English law should be interpreted as they would be in England ${ }^{104}$; and this trend naturally became stronger after Independence - particularly after the official severance of the interpretation provisions from the English law ${ }^{105}$. Moreover, if it were surmised that the Criminal Code Ordinance would be interpreted in accordance with the interpretations which prevailed in the other colonies, or former colonies, in which the same or a similar code was in force, Abrams (1972) and Shachar (1979) have pointed out that the Israel judiciary was almost totally unaware of the case-law of those other jurisdictions; and in some areas new interpretations have emerged, supposedly attuned to Israeli conditions. The issuance of the official Hebrew version of the Code in 1977 would lend further support to the concept of an independent development, as, a fortiori, would the numerous legislative amendments which have taken place since the original Code was introduced - and in particular those introduced since the independence of the state.

(3) A third explanation for the post-colonial society's adherence to the colonial norms might be that whatever the prior values and normative patterns of a society, the imposition of a new code will have a momentum of its own, and will give rise to an internalisation of the values underlying that code. This view is perhaps implicit in the Austinian "command" theory of law, and is reflected in the view of Andenaes (1974), who has argued that sanctioning principles laid down by the legislature infiltrate into the normative attitudes of subsequent generations. Following this line of argument, even if the colonial societies differed culturally and normatively at the time when the codes were adopted, both from the mother country and from the other societies in which the code's norms prevailed, during the course of time they would become similar, as a result of the application of the code to that society.

This analysis raises the issue of the relationship between legal norms and social or cultural norms, for it assumes that social norms are determined by legal norms rather than vice versa. While the "social engineering" school attributed to the law

\footnotetext{
102 See Turner (1978). 
some potential for social change, this was generally applied within the parameters of a particular political culture ${ }^{106}$. Moreover legal philosophers with a more historical or cultural orientation, such as Savigny or Sumner, would certainly question such a vision of socio-legal development ${ }^{107}$ - as would the post-modernists ${ }^{108}$.

(4) Yet another approach would accept the existence of cultural and normative diversity among nations and would deny the power of an imposed law either to adapt itself to the local normative system or to remove the diversity among the different systems. It would rather argue that a gap between the official legal norms and popular norms was created by the imperial bureaucracy during the colonial period and that this gap was maintained following independence by a "New Class" of lawyer-bureaucrats, reluctant to alter a system with which they were familiar.

In principle this approach is consistent with the bureaucratic model of legislation described earlier in the article. In many instances, however, it may also be consistent with a conflict analysis. For while on the one hand, as noted above, the colonial legislation enacted during the imperial period may be perceived as an instrument for the subjugation of the local population, and thus no longer relevant, in many former colonies the tension between a dominant and a native population (or minority) remains - and the colonial legal structure will be serving the interests not merely of a bureaucracy, but of a class, race or ethnic group ${ }^{109}$.

The more valid of the explanations for the retention of the colonial codes in general, and in Israel in particular, seems to be some combination of the second approach, which lays emphasis on the autonomous development of the codes, and the last one, whether in its bureaucratic or its conflict form ${ }^{100}$, which emphasises the interest of the powers-that-be in the continuity of the colonial system.

\section{FINAL NOTE}

A detailed study of the nature and history of the codes of a variety of former colonies might provide answers to a number of questions, and enable some hypotheses to be tested in connection with the interrelationship of some of the variables referred to here. For example: How far is there a connection between the duration of the retention of the colonial code and its content? It could be hypothesized here that a more "universalist" code, drafted in the spirit of the utilitarians, would endure longer than a code based exclusively upon the law of the imperial power. Secondly, have the codes been longer retained in former colonies in which there is a disadvantaged (usually native) minority? A positive finding would be hypothesized here. Finally, it may also be of interest to study the connection between the nature of the independence process (in particular the degree of conflict

106 Cf. Evan (1980).

107 Cf. Cotterrell (1992, chapter 1).

108 See, e.g., Freeman (1994, chapter 14).

109 See, e.g., Hazlehurst (1995).

110 In Israel some elements of the colonial legislation were clearly retained in order to control the Arab population, who were seen as a security threat. 
involved) and the other variables referred to ${ }^{111}$. Here it would be hypothesized that a smoother passage to independence (evolutionary, rather than revolutionary) would increase the probability that the code would be retained. Further research is required in order to explore these issues.

\author{
Leslie Sebba \\ Institute of Criminology \\ Faculty of Law \\ Hebrew University of Jerusalem \\ Mount Scopus \\ Jerusalem 91905 \\ E-mail:mssebba@mscc.huji.ac.il
}

\title{
REFERENCES
}

Abrams, N., Interpreting the Criminal Code Ordinance, 1936: The untapped well, Israel Law Review, 1972, 7, p. 25-64.

Andenaes, J., Punishment and Deterrence, Ann Arbor, University of Michigan Press, 1974. Bar-Niv, Z., The Role of The Civil Servant in Legislation, Jerusalem, Hebrew University, 1971 (in Hebrew).

Bannerjee, T., Background to Indian Criminal Law, Bombay, Orient Longmans, 1963.

Bein, D., Criminal law, in Zamir, I., and Colombo, S., (Eds), The Law of Israel: General Surveys, Jerusalem, Hebrew University, 1995, p. 127-195.

Berk, R.A., Brackman, H., Lesser, S., A Measure of Justice, New York, Academic Press, 1977.

Brown, D.H., The Genesis of the Criminal Code of 1892, Toronto, University of Toronto, 1989.

Burman, S.B., Harrell-Bond, B.E., (Eds), The Imposition of Law, New York, Academic Press, 1979.

Chambliss, W.J., A sociological analysis of the law of vagrancy, Social Problems, 1964, 12, p. 67-77.

Chambliss, W.J., The State and criminal law, in Chambliss, W.J., Mankoff, M., (Eds), Whose Law - What Order?, New York, Wiley, 1976, p. 66-106.

Chambliss, W.J., On lawmaking, in Chambliss, W.J., Zatz, M.S., (Eds), Making Law: The State, the Law, and Structural Contradictions, Indiana University Press, 1993, p. 3-35.

Char, S.V.D., Centralised Legislation, Bombay, Asian Publishing House, 1963.

Cotterrell, R., The Sociology of Law, London, Butterworths, $2^{\text {nd }}$ ed., 1992.

Cross, R., The making of English criminal law: (5) Macaulay, Criminal Law Review, 1978, p. 519-528.

Darian-Smith, E., Postcolonialism: a brief introduction, Social and Legal Studies, 1996, p. 291-299.

Dhagamwar, V., Law, Power and Justice: The Protection of Personal Rights in the Indian Penal Code, Newbury Park, Sage, 1992.

Dharker, C.D., Lond Macaulay' Legislative Minutes, London, Oxford University Press, 1946. Elias, T.O., British Colonial Law, London, Stevens, 1962.

111 Cf. Rabello and Sebba (1994). 
Evan, W.M., Law as an instrument of social change, in Evan, W.M., (Ed.), The Sociology of Law: A Social-Structural Perspective, New York, Free Press, 1980, p. 554-562.

Freeman, M.D.A., Lloyd's Introduction to Jurisprudence, $6^{\text {th }}$ ed., London, Sweet and Maxwell, 1994.

Friedland, M.L., A Century of Criminal Justice, Agincourt, Ont., Carswell, 1984.

Ghai, Y., et al., (Eds), The Political Economy of Law: A Third World Reader, New Delhi, Oxford University Press, 1987.

Hagan, J., The legislation of crime and delinquency: a review of theory. Method and Research, Law and Society Review, 1980, 14, p. 603-628.

Hall, J., Theft, Law and Society, Indianapolis, Bobbs Merrill, 1952.

Hazlehurst, K.M., Legal Pluralism and the Colonial Legacy: Indigenous Experiences of Justice in Canada, Australia, and New Zealand, Aldershot, Avebury, 1995.

Jain, M.P., Outlines of Indian Legal History, Bombay, Tripathi, 1977.

Kadish, S.H., Codifiers of the criminal law: Wechsler's predecessors, Columbia Law Review, 1978,78 , p. $1098-1144$.

Kidder, R.L., Toward an integrated theory of imposed law, in Burman, S.B., Harrell-Bond, B.R., (Eds), The Imposition of Law, New York, Academic Press, 1979, p. 289-306.

Likhovski, A., In our image: colonial discourse and the anglicization of the law of mandatory Palestine, Israel Law Review, 1995, 29, p. 291-359.

Lloyd, Lord, Freeman, M.D.A., Introduction to Jurisprudence, $4^{\text {th }}$ ed., London, Stevens and Sons, 1979.

Mannheim., H., Comparative Criminology, London, Routledge and Kegan Paul, 1965.

McCoy, C., Politics and Plea Bargaining, Philadelphia, University of Pennsylvania Press, 1993.

McDonald, The Sociology of Law and Order, London, Faber and Faber, 1976.

Merry, S.E., Law and colonialism, Law and Society Review, 1991, 25, p. 889-922.

Mezey, M.L., Comparative Legislatures, Durham, N.C, Duke University Press, 1979.

Miers, D.R., Page, A.C., Legislation, London, Sweet and Maxwell, $2^{\text {nd }}$ ed., 1990.

Morris, H.F., How Nigeria got its code, Journal of African Law, 1970, 14, p. 137-154.

Morris, H.F., A History of the adoption of codes of criminal law and procedure in British colonial Africa, 1876-1935, Journal of African Law, 1974, 18, p. 6-23.

Newman, G., Comparative Deviance, New York, Elsevier, 1976.

Potter, D.C., India's Political Administrators 1919-1983, Oxford, Clarendon Press, 1986.

Rabello, A.M., Sebba, L., Continuity and discontinuity in times of social revolution: the case of Israel, in Rabello, A.M., (Ed.), Israeli Reports to the XIV International Congress of Comparative Law, Jerusalem, Hebrew University, 1994, p. 1-16.

Rock, P., A View from the Shadows, Oxford, Clarendon Press, 1986.

Scheingold, S.A., Olson, T., Pershing, J., Sexual violence, victim advocacy, and republican criminology: Washington State's Community Protection Act, Law and Society Review, $1994,28,729-63$.

Sebba, L., The requirement of corroboration in sex offences, Israel Law Review, 1968, 3, p. 67-87.

Sebba, L., Professor Tedeschi and 'The jurisprudence of legislation' - A voice in the wilderness, in Englard, Y., et al. (Eds), In Memory of Guido Tedeschi, Jerusalem, Hebrew University, 1995, p. 535-562.

Shachar, Y., The sources of the criminal code ordinance 1936, Iyunei Mishpat, 1979, 7, p. 75113 (in Hebrew: English summary, p. 256-258).

Shachar, Y., The diary of Uri Yadin, Iyunei Mishpat, 1992, 16, p. 537-557 (in Hebrew).

Stokes, E., The English Utilitarians and India, Oxford, Clarendon Press, 1959. 
Sumner, C., Crime, justice and underdevelopment: beyond modernisation theory, in Sumner, C., (Ed.), Crime, Justice and Underdevelopment, London, Heinemann, 1982, p. 1-39. Tomasic, R., The sociology of legislation, in Tomasic, R. (Ed.), Legislation and Society in Australia, Sydney, Allen and Unwin, 1980, p. 19-49.

Thompson, E.P., Whigs and Hunters: The Origin of the Black Act, Harmondsworth, Penguin, 1975.

Turner, S., Introduction, in Sellin, T., Wolfgang, M.E. (Eds), The Measurement of Delinquency, New York, Elsevier, 1964-1978.

Zander, M., The Law-Making Process, London, Butterworths, $4^{\text {th }}$ ed., 1994.

Zatz, M.S., Preface, in Chambliss, W.J., Zatz, M.S., (Eds), Making Law: The State, the Law, and Structural Contradictions, Bloomington, Indiana University Press, 1993, p. ix-xi. 